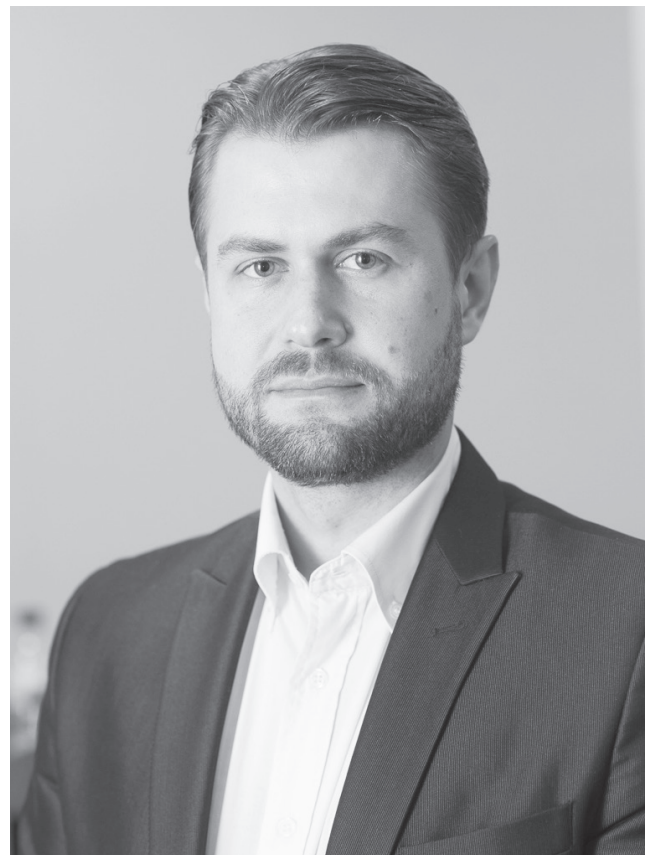

Серняк Олег Игоревич,
UDC: $351: 378+327$

DOI: https://doi.org/10.32689/2617-

2224-2019-5(20)-198-209

Serniak Oleh Ihorovych,

PhD in Public Administration, Associate Professor at the Department of Public Management and Administration of the IvanoFrankivsk National Technical University of Oil and Gas; 76019, Ivano-Frankivsk, Carpathian Str., 15; oleh_sernyak@ukr.net; +38 (066) 246-90-45

ORCID: 0000-0002-8935-3253

\section{Серняк Олег Ігорович,}

кандидат наук з державного управління, дочент кафедри публічного управління та адміністрування Івано-Франківського начіонального технічного університету нафти і газу; 76019, м. Івано-Франківськ, вул. Карпатська, 15; oleh sernyak@ukr.net; +38(066)246-90-45

ORCID: 0000-0002-8935-3253

кандидат наук по государственному управлению, доцент кафедры публичного управления и администрирования Ивано-Франковского начионального технического университета нефти и газа; 76019, г. Ивано-Франковск, ул. Карпатская, 15; оleh sernyak@ukr.net; +38 (066) 246-90-45

\title{
"DEMONOPOLIZATION" OF HIGHER EDUCATION AS A COMPONENT OF NATIONAL SECURITY OF UKRAINE (ARCHETYPAL APPROACH)
}

Abstract. The article deals with the intermediate results of the reform of higher education in Ukraine in accordance with the standard law. Examples of qualitative changes to reduce the burden on teachers, the prohibition of the combination of administrative positions at universities, transparency of the universities' activities and the growth of student self-government rights are given. At the same time, there are several archetypes that impede the implementation of effective educational changes and which pose a potential threat to the national security of the state. All of them are reduced to the concept of "monopolization" of higher education as the concentration of key competences in this area, in particular in terms of ensuring the quality of education, in the hands of one (the ministry) or several interrelated public institutions (ministry, national quality agency, Public service of quality of education). 
Such archetypes are bureaucracy and inflexibility of the Ukrainian universities, which prevents them from competing on an equal footing with educational institutions of European countries; their organizational dependence on paternalism by the ministry and other institutions of power, on the one hand, and the excessive paternalism and reluctance of the state to delegate authority over the development of real university autonomy, on the other; the failure of public institutions in education to work on the principle of a project office with the transition to coordinating and monitoring functions; the refusal of the university environment and the ministry to recognize the public in the person of students, their parents and employers as equal partners in the processes of quality education management.

In order to change the last archetype that some scholars call the "semantic core" of the whole model of higher education, it is proposed to create in Ukraine an institute of independent educational auditors as a mechanism of direct influence of the public and beneficiaries on the processes of higher education quality ensuring. The purpose of such an audit, its advantages for universities, the requirements to the professional level of the auditors themselves, organizational aspects and risks of the functioning of the institute of independent educational auditors are considered.

Keywords: public administration, higher education, "demonopolization" of higher education, quality assurance in higher education, national security, archetype, independent educational auditor.

\section{“ДЕМОНОПОЛІЗАЦЯ” ВИЩОЇ ОСВІТИ ЯК СКЛАДОВА НАЦІОНАЛЬНОЇ БЕЗПЕКИ УКРАЇНИ (АРХЕТИПНИЙ ПІДХІД)}

Анотація. Розглянуто проміжні результати реформування вищої освіти в Україні відповідно до профільного закону. Наведено приклади якісних змін щодо зменшення навантаження викладачів, заборони суміщення адміністративних посад в університетах, системи рівнів освіти, підвищення прозорості діяльності вузів і зростання прав студентського самоврядування. Водночас виокремлено кілька архетипів, які заважають впровадженню ефективних освітніх змін і які становлять потенційну загрозу національній безпеці держави. Вони усі зводяться до поняття “монополізації” вищої освіти як концентрації ключових повноважень у цій сфері, зокрема щодо забезпечення якості освіти, в руках однієї (міністерства) чи кількох пов'язаних між собою державних інституцій (міністерство, НАЗЯВО, Державна служба якості освіти).

Такими архетипами є забюрократизованість та негнучкість університетів України, що не дозволяе їм конкурувати на рівних з освітніми закладами європейських країн; ї організаційна залежність від патерналізму 3 боку міністерства та інших інституцій влади, з одного боку, та надмірний патерналізм і небажання держави делегувати повноваження щодо розвитку реальної університетської автономії, з іншого; неспроможність державних інституцій в освіті працювати за принципом проектного офісу з переходом виключно до координуючої та моніторингової функцій; відмова з боку уні- 
верситетського середовища і міністерства визнавати громадськість в особі студентів, їх батьків і роботодавців як рівноправних партнерів у процесах управління якістю освіти.

Для зміни останнього архетипу, який окремі науковці називають “смисловим ядром” всієї моделі вищої освіти, запропоновано створити в Україні інститут незалежних освітніх аудиторів як механізм безпосереднього впливу громадськості та бенефіціарів на процеси забезпечення якості вищої освіти. Розглянуто мету такого аудиту, його переваги для університетів, вимоги до професійного рівня самих аудиторів, організаційні аспекти й ризики функціонування інституту незалежних освітніх аудиторів.

Ключові слова: публічне управління, вища освіта, “демонополізація” вищої освіти, забезпечення якості вищої освіти, національна безпека, архетип, незалежний освітній аудитор.

\section{“ДЕМОНОПОЛИЗАЦИЯ” ВЫСШЕГО ОБРАЗОВАНИЯ КАК СОСТАВЛЯЮЩАЯ НАЦИОНАЛЬНОЙ БЕЗОПАСНОСТИ УКРАИНЫ (АРХЕТИПНЫЙ ПОДХОД)}

Аннотация. Рассмотрены промежуточные результаты реформирования высшего образования в Украине в соответствии с профильным законом. Приведены примеры качественных изменений по уменьшению нагрузки преподавателей, запрету совмещения административных должностей в университетах, повышению прозрачности деятельности вузов и росту прав студенческого самоуправления. В то же время выделены несколько архетипов, которые мешают внедрению эффективных образовательных изменений и которые представляют потенциальную угрозу национальной безопасности государства. Они все сводятся к понятию “монополизации” высшего образования как концентрации ключевых полномочий в этой сфере, в частности по обеспечению качества образования, в руках одного (министерства) или нескольких связанных между собой государственных институтов (министерство, НАЗЯВО, Государственная служба качества образования).

Такими архетипами являются забюрократизированность и негибкость университетов Украины, что не позволяет им конкурировать на равных с образовательными учреждениями европейских стран; их организационная зависимость от патернализма со стороны министерства и других институтов власти, с одной стороны, и чрезмерный патернализм и нежелание государства делегировать полномочия по развитию реальной университетской автономии, з другой; несостоятельность высших государственных институтов работать по принципу проектного офиса с переходом исключительно к координирующей и мониторинговой функции; отказ со стороны университетской среды и министерства признавать общественность в лице студентов, их родителей и работодателей как равноправных партнеров в процессах управления качеством образования.

Для изменения последнего архетипа, который отдельные ученые называют “смысловым ядром” всей модели высшего образования, предложено 
создать в Украине институт независимых образовательных аудиторов как механизм непосредственного влияния общественности и бенефициаров на процессы обеспечения качества высшего образования. Рассмотрены цель такого аудита, его преимущества для университетов, требования к профессиональному уровню самих аудиторов, организационные аспекты и риски функционирования института независимых образовательных аудиторов.

Ключевые слова: государственное управление, высшее образование, “демонополизация” высшего образования, обеспечение качества высшего образования, национальная безопасность, архетип, независимый образовательный аудитор.

Formulation of the problem. For the past five years the national security has been setting the agenda for Ukraine's domestic and foreign policy. The efforts of the highest institutions of the public authorities, the public and the mass media are bound to it. The Cabinet of Ministers of Ukraine has provided 212 billion UAH to ensure the defense of the state and the security of its citizens (5,4\% of GDP) for 2019, up by 33,3 billion UAH exceeds the previous year's expenditures. However, Ukraine's national security system is still weak in the face of numerous challenges and is conditioned by the fact that it covers not only the defense sphere and counteracting external threats, but also affects all the vital interests of the individual, society and state, whose realization is guaranteed by the state sovereignty of Ukraine, its progressive democratic development, as well as safe living conditions and well-being of its citizens.

One area that has an indirect impact on the national security of the state is education in general and higher education in particular. On the one hand, due to the educational institutions the potential of the security and defense sphere is formed, and on the other - the level of education determines the civic and political activity, the willingness to put national interests above the personal ones. Therefore, in order to strengthen Ukraine's national security it is important today to step up the educational reform processes, especially in the higher education, to rethink the paternalistic archetype of the ministry scientifically, and finally to move from centralized management to university autonomy, public monitoring and control in this field.

Analysis of the recent research and publications. The analytical report of the National Institute for Strategic Studies "Security Dimensions of the Educational Policy: World Experience and Ukrainian Realities" (2017) is devoted to the development of the education as a component of Ukraine's national security. The study, in particular, covered the issues of formation of the safety criteria in the education, solving the main tasks of reforming the educational and scientific sphere, identifying and overcoming the problem areas in the education system, neutralizing the negative impact of the Russian military aggression on the education system [1]. E. Krasnyakov, E. Luzik, T. Lukina, I. Musiyenko, O. Tarasenko, 
L. Khomenko-Semenova, L. Chupriy and other scientists also paid attention to the problems of the influence of the education on strengthening the national security of the state at different times. However, the question of the direct relationship between the archetypes in the public administration, decentralization and deregulation of the higher education in Ukraine and the national security has not been the subject of scientific research.

Formulation of the purposes (goal) of the article. Describe the results of the reform of the higher education system in Ukraine after the introduction of the Law "On Higher Education"; outline the main archetypes that hinder the qualitative changes in the higher education system; propose ways of "demonopolizing" the higher education and enhancing the role of the public and beneficiaries in the quality assurance of the higher education.

Presentation of the main material. The adoption of the Law of Ukraine "On Higher Education" of 01.07.2014 marked several revolutionary systemic changes in the field of the higher education. First of all, it is the academic and financial autonomy of the educational institution, the transfer of a large part of the powers in the field of quality assurance of the higher education to an independent institution "National Agency for Quality Assurance in the Higher Education (NAQAHE)", the termination of the usurpation of the power in the universities, the fight against scientific plagiarism, other important innovations [2]. However, more than 4,5 years have passed since the Law "On Higher Education" was passed and during this time real changes have occurred except for reducing the workload of the teachers, banning administrative positions at the universities, education levels, increasing transparency of the higher education and increasing the student self-government rights. And the staff of the NAQAHE was formed at the end of 2018 and only on the second attempt.

Even the leadership of the Ministry of Education and Science of Ukraine has alarmed the situation with the implementation of the law on the bureaucracy and decentralization of the powers at the university level. Thus, the Minister of Education and Science of Ukraine Liliya Grynevych, during a meeting of the Enlarged Board of the Ministry of Education and Science on January 26, 2018 emphasized that "the broad autonomy of the universities has widened the gap between the leading universities and the "others". The first took the opportunity - introduced new educational programs, attracted employers, entered international projects, learned to plan the educational process reasonably, engaged in the commercialization of their own research, trying to create competition in the market of the educational services. The "others" have encapsulated in their inability to effectively manage" [3]. As a result, the profile ministry discussed the obsolescence of the law and the need to amend it.

An interim analysis of the first "fiveyear" reform of the higher education in Ukraine identifies several archetypes that impede the implementation of effective educational change and that pose a potential threat to the national security of the state. They can all be reduced to the concept of "monopolization" of the higher education in Ukraine, represented by the ministry 
and other state institutions, as a concentration of key powers in this area, in particular to ensure the quality of the education, in the hands of one (ministry) or several related state institutions (ministry, NAQAHE, State Education Quality Service).

The first archetype - the universities in Ukraine - is too bureaucratic and inflexible, which prevents them from competing on an equal footing with the educational institutions of the European countries. And here it is difficult to argue, because according to the results of the study of the CEDOS think tank in the 2015-2016 academic year more than 30 thousand Ukrainian students studied in Poland alone, and a total of about 70 thousand of our citizens studied abroad during this period [4]. As a result, the competition between the Ukrainian universities for students often becomes the plane of competition between "required ties" in the ministry when awarding a state contract or undergoing the licensing and accreditation procedures. As the new law did not break these "schemes", the higher education institutions will not be changed for the most part.

The second is that domestic universities need paternalism on the part of the ministry and other institutions of power. The universities management is a specialist in the scientific and pedagogical field, but often unprofessional in the administration field. Therefore, organizing the processes or creating a regulatory field within the university becomes an almost impossible task. Instead, it is more convenient and easier to follow the instructions or directives from the "above". At the same time, and the Ministry of Education and Science is not ready to fully comply with the requirements of the Law "On Higher Education" regarding the transfer of powers to the level of the higher education institutions, in particular the right to recognize foreign diplomas and degrees, the right to award scientific degrees, the right of the universities to issue their own diplomas alongside the state ones. This "vitality" of the archetype of paternalism is attributed by many scholars by the subconscious attraction to the Byzantine tradition and, to a greater degree, by the Eastern, than the Western mentality of the Ukrainians. But in our opinion, it is solely due to the nature of man, the unwillingness to step out of the comfort zone, initiate decisions and take responsibility for their realization.

The third archetype is that the public institutions do not perform well on the project office principle, and therefore it is not necessary to expect complete "demonopolisation" of the higher education, which entails massive cuts in the civil servants and the transition to coordinating and monitoring functions. In a society where education, science and medicine are almost untouched areas, such a move can be interpreted as the "destruction", sabotage and undermining of the national security. Although in reality the poor quality of the services in these areas is a major threat to the national security of the state.

The fourth archetype - for the ministry and national universities the public can be involved in the higher education processes only as entrants and as employers. Only MES (Ministry of Education and Science), state and quasi-state (NAQAHE) institutions are 
competent to monitor and influence the quality of the higher education. This archetype is quite difficult to rethink in public consciousness. On the one hand, the entrants, students, their parents, employers and public organizations do not believe in their own power to participate in the quality of the higher education and to really influence what is happening in the universities, on the other - the teaching and university environment is not ready to communicate with the beneficiaries of the educational services on a partnership basis.

In our view, the most complex archetypal phenomenon in the higher education that needs dramatic and decisive changes in the direction of "demonopolization" is the involvement of the public in the quality management of the higher education. The domestic scientist Yu. Fedorchenko calls this sphere the "semantic core" of the whole model of the higher education and determines the importance of its reform [5]. According to the Law of Ukraine "On Higher Education", the function of quality assurance of the higher education of the Ministry of Education and Science should be transferred to the NAQAHE. But it seems that the lawmakers themselves did not believe in the ability of this institution to provide the quality of the higher education in Ukraine, and therefore decided to insure it with industry expert councils and a structure for any bureaucratic organization that would actually carry out all the work of the quality assurance institution - by the secretariat. In addition, to curb the National Agency's excessive autonomy, its most important decisions are to formulate requirements for the quality assurance system of the higher education, to develop regulations on the accreditation of the educational programs, to develop requirements for the level of scientific qualification of the persons who obtain scientific degrees, and the procedure for awarding them by specialized scientific councils of the educational institutions (scientific institutions) - will become effective only after the approval by the Ministry of Education and Science of Ukraine.

Therefore, the situation with the quality assurance of the higher education in Ukraine remains extremely troubling. On the one hand, the state does not intend to lose monopoly control over the sphere of licensing and accreditation of the higher education institutions and awarding scientific degrees, and on the other, the outflow of the Ukrainian students abroad and the lack of qualified personnel in different sectors of the Ukrainian economy prompts them to seek innovative ways of ensuring the quality of the higher education. One of them is the creation of an institute of independent educational auditors.

The purpose of an independent educational audit is to confirm the compliance of the quality level of the higher education in the universities with the established regulatory requirements, which is identical to passing the licensing and accreditation procedure, and to make practical recommendations for improving the quality of the higher education. The difference between an independent educational audit and a traditional accreditation lies in the right of the management of the educational institution to decide independently what to do with the report: 
- in the case of a positive conclusion, publish it, and it is up to the students and employers to decide whether to trust the conclusion and the auditor;

- in the case of a negative conclusion, improve the non-standard components of the educational activities of the universities and then re-use the services of an independent educational auditor.

Based on the essence of an independent educational audit as an examination of the quality of the higher education voluntarily commissioned by the higher education institutions on the basis of a agreement with the use of predefined types, time and forms of examination, subject to the conditions of complete confidentiality of the obtained results, it is possible to distinguish its main advantages for the higher educational institutions:

- opportunity to obtain an independent assessment of the quality of the educational programs and training of the specialists, to avoid the directive influence of the state institutions on the activities of the higher education institutions;

- independent educational audit does not violate the independence of the higher education institutions and encourages the educational organizations to develop and effectively operate their own internal systems of assessment and quality assurance of the higher education;

- transfer of the licensing and accreditation procedures from the field of formal quantitative indicators to the realm of improving the quality of the education, which is an important factor in improving the competitiveness of the higher education institutions in the educational services market;
- independent educational audit enables to publicly declare the high level of quality of training of the specialists in this higher education institution, to win and strengthen the position of the educational organization in the international market of educational services, to improve the employment of the graduates.

The functioning of the institute of the independent educational auditors is in line with the provisions of the "Standards and Recommendations for Quality Assurance in the European Higher Education Area" of 2015, in particular as regards the mandate of a group of independent (external) experts, comprising a student representative(s), and takes into account different points of view of the stakeholders, including educational institutions, teachers, students and employers/practitioners [6].

The introduction of the institute of the independent educational auditors places stringent requirements on the professional level of the auditors themselves. They must have the necessary skills and competencies to accomplish their tasks, undergo proper training and constantly improve their professional level. Of course, it is possible to involve international experts in an independent educational audit, but it would be more efficient to use their knowledge and experience to train independent educational auditors in Ukraine and to develop the standards for such an audit.

The activities of the independent educational auditors should be subject to mandatory certification. According to Article 23, paragraph 1 of the Law of Ukraine "On Higher Education" the independent institutions for quality assessment and quality assurance are 
accredited by the NAQAHE [7]. This automatically guarantees the certification of all the persons working in the organization. However, in our view, the certification process adopted in auditing is more effective and objective. The certification of the auditors is carried out by passing a written qualification examination according to the program approved by the Audit Chamber of Ukraine, which is an independent non-profit organization. The certificate may not exceed five years and may be renewed for five years following the results of the specialty testing in accordance with the procedure established by the Audit Chamber of Ukraine [8].

Accordingly, the certification of the independent educational auditors should be carried out by a non-profit public organization of the independent educational auditors of Ukraine under their own programs of primary and recertification that will be based on the best foreign experience. However, before setting up such an organization, it is advisable to select and train at least ten independent educational auditors for grants and under the control of the international institutions for quality assurance in the higher education, which will subsequently become the founders of the public organization.

This public organization should independently determine the educational requirements and level of the professional training of the independent educational auditors, organize their training and regular certification training. It will oversee the activities of all the independent educational auditors to comply with their standards of the professional ethics and, if these requirements are violated, will deprive specific persons of the right to audit. So, one must be aware of the potential risks associated with the overestimation of the services of the independent educational auditors, the excessive formalism of the audit process, or the prospect of turning them into puppets of the major universities. But all these phenomena on the part of the state institutions can be observed today and even on a larger scale. Therefore, the potential threats should be addressed from the beginning of the establishment of the institute of the educational auditors, developing transparent and understandable rules for all the market players, constantly increasing the requirements for the auditors and at the same time the prestige of their work, involving as many interested parties as possible, including international organizations, in this process, mass media and public organizations. Only in this case will the educational audit become a truly independent mechanism for the public oversight of the quality of the higher education in Ukraine.

It is clear that the introduction of the institute of the independent educational auditors and the "demonopolisation" of the higher education in general will meet many opponents, both among the officials of the Ministry of Education and Science of Ukraine and among unscrupulous heads of the educational institutions who have been accustomed to treading corruption for years. But people and organizations are many times more interested in implementing this idea. These are also progressive higher institutions, that today actively care about the quality of education (in particular, National University "KyivMohyla Academy", National University "Lviv Polytechnic", Ukrainian Cath- 
olic University, National University "Ostroh Academy" and others), and the public organizations and movements (Chesno, Opora, Anti-Corruption Center and others), and students, and the academic community, and the business environment, and the state of Ukraine in general.

The introduction of the institute of independent educational auditors involves quite a lot of work. The first stage is the preparation and adoption of the Law of Ukraine "On Independent Educational Audit". This advocacy campaign will also develop the concept of functioning of the institute of the independent educational auditors based on the Standards and Recommendations for Quality Assurance in the European Higher Education Area, conduct an awareness campaign on the need to enhance the quality of the education of the higher education institutions and to create an image of an educational auditor as a partner of this process, development of the procedures for the training of the educational auditors and methods of conducting an independent educational audit.

Thus, an independent educational audit is not a panacea for all the problems of the higher education. But it is a sure step towards the transparency of the licensing and accreditation processes closed so far from the public, as well as the freedom of choice of the educational audit entities by the educational institutions and, as a consequence, the loss of the state's monopoly over these processes. The active involvement of the public, professionals and international experts in improving the effectiveness of the educational services guarantees in the medium term the im- provement of the quality of education and science in Ukraine, and through it, the enhancement of the Ukraine's national security.

Conclusions and prospects for further research. The archetypes of the public administration are present in all its spheres, including in the higher education management. It is about excessive bureaucratization of the processes, centralization of decision making, "monopolization" of the most important areas of activity. This is due both to the very nature of the management activities and to the lack of initiative, innovation, mutual trust between the persons involved in the educational processes and the beneficiaries of the educational services.

The state continues to maintain monopoly control over the quality assurance in the field of the higher education, but the outflow of the Ukrainian students abroad and the lack of qualified staff in various sectors of Ukraine's economy testify to the ineffectiveness of this mechanism. At the same time, these negative trends pose a direct threat to the national security of the state.

A systematic involvement of the public in the higher education quality management is required to make dramatic and decisive changes towards the "demonopolization" of the higher education. Such a mechanism could be the creation of an institute of independent educational auditors, that would be engaged in confirming the compliance of the quality level of the higher education in the higher education with the established regulatory requirements, which is identical to the passing of the licensing and accreditation procedure, with the obligatory development of the 
practical recommendations for the improvement of the quality of the higher education in a particular higher institution.

By representing and acting for the benefit of the public and beneficiaries of the educational services, the independent educational auditors can both improve the competitiveness of the national education and, in the short term, improve the quality of the educational services in line with the public demand and global educational trends. Being a public institute, having natural institutional flexibility and having minimal political will on the part of the government institutions, the independent educational auditors can change the organizational archetypes of the higher education system, make it more open, adaptive and effective.

If these innovations are successfully implemented, it will be possible to get rid of the state's monopoly over the licensing and accreditation processes and launch a mechanism of the professional public control over this area, encourage the universities themselves to take care of constantly improving the quality of the higher education, since there will be no other way (shadow, corruption) for them to exist. It will be a revolutionaryevolutionary path of development of the higher education of Ukraine that eliminates the key internal threats to the national security of the state.

\section{REFERENCES}

1. Chernenko T. V., Karpenko M. M., Lozovyi V. S., Zubchenko S. O., \& Ishchenko A.Yu. (2017). Bezpekovi vymiry osvitnoi polityky: svitovyi dosvid i ukrainski realii [Security Measures of Educational Policy: World
Experience and Ukrainian Realities]. Natsionalnyi instytut stratehichnykh doslidjen - National Institute for Strategic Studies. Retrieved from http:// www.niss.gov.ua/content/articles/ files/Osvita_Bezpeka-40c41.pdf [in Ukrainian].

2. Shamaida T. (2014). 16 revolyutsiinykh zmin u vyshchiy osviti: Novyi zakon pochav diyaty [16 Revolutionary Changes in Higher Education: The New Law Began to Operate]. Nezalejne Internet-vydannia "TEXTY. ORG.UA" - Independent Online Edition "TEXTY.ORG.UA". Retrieved from http://texty.org.ua/pg/article/textynewseditor/read/55679/16_revolucijnyh_zmin_u_vyshhij_osviti_Novyj [in Ukrainian].

3. Liliia Hrynevych: Pryiniatyi u 2014mu ZU "Pro vyshchu osvitu" zaprovadyv bahato potribnykh novatsii, ale sohodni vin uje zastariv i potrebue zmin [Lilia Hrynevych: In 2014, the Law on Higher Education Introduced Many Necessary Innovations, but Today It is Outdated and Needs to be Changed]. (2018). Ministerstvo osvity i nauky Ukrainy: ofitsiinyi sait Ministry of Education and Science of Ukraine: official site. Retrieved from https://mon.gov.ua/ua/news/ liliya-grinevich-prijnyatij-u-2014-muzu-pro-vishu-osvitu-zaprovadivbagato-potribnih-novacij-ale-sogodnivin-uzhe-zastariv-ta-potrebuye-zmin [in Ukrainian].

4. Stadnyi Ye. (2017). Ukrainski studenty zakordonom: fakty ta stereotypy [Ukrainian Students Abroad: Facts and Stereotypes]. Analitychnyi tsentr CEDOS - CEDOS Think Tank. Retrieved from https://cedos.org. ua/uk/articles/ukrainski-studentyza-kordonom-fakty-ta-stereotypy [in Ukrainian].

5. Fedorchenko Yu. (2018). Chy treba radykalno miniaty zakon "Pro vysh- 
chu osvitu"? [Do It Need to Radically Change the Law "On Higher Education”?]. Osvita.ua - Education.ua. Retrieved from https://osvita.ua/vnz/ reform/59677/ [in Ukrainian].

6. Standarty $i$ rekomendatsii shchodo zabezpechennia yakosti v Yevropeiskomu prostori vyshchoi osvity (ESG) [Standards and Recommendations for Quality Assurance in the European Higher Education Area (ESG)]. (2015). Kyiv: TOV “TsS” [in Ukrainian].

7. Zakon Ukrainy Pro vyshchu osvitu : pryiniatyi 1 lyp. 2014 roku № 1556VII [Law of Ukraine on higher education from July 1 2014, № 1556-VII]. Verkhovna Rada Ukrainy - Verkhovna Rada of Ukraine. Retrieved from http://zakon4.rada.gov.ua/laws/ show/1556-18 [in Ukrainian].

8. Zakon Ukrainy Pro audytorsku diialnist : pryiniatyi 22 kvit. 1993 roku № 3125-XII [Law of Ukraine on audit activity from April 22 1993, № 3125-XII]. Verkhoona Rada Ukrainy - Verkhovna Rada of Ukraine. Retrieved from http://zakon4.rada. gov.ua/laws/show/3125-12 [in Ukrainian].

\section{СПИСОК ВИКОРИСТАНИХ ДЖЕРЕЛ}

1. Безпекові виміри освітньої політики: світовий досвід і українські реалії: аналітична доповідь [Електронний ресурс] / Т. В. Черненко, М. М. Карпенко, В. С. Лозовий, С. О. Зубченко, А. Ю. Іщенко // Нац. ін-т стратегічних досліджень. 2017. Режим доступу : http://www. niss.gov.ua/content/articles/files/ Osvita_Bezpeka-40c41.pdf.

2. Шамайда T. 16 революційних змін у вищій освіті: Новий закон почав діяти [Електронний ресурс] / T. Шамайда // Незалежне Інтер- нет-видання

“TEXTY.ORG.UA".

2014. Режим доступу : http://texty. org.ua/pg/article/textynewseditor/ read/55679/16_revolucijnyh_ zmin_u_vyshhij_osviti_Novyj

3. Лілія Гриневич: Прийнятий у 2014му ЗУ “Про вищу освіту" запровадив багато потрібних новацій, але сьогодні він уже застарів та потребує змін / / М-во освіти і науки України : офіц. сайт. 2018. Режим доступу: https://mon.gov.ua/ua/news/ liliya-grinevich-prijnyatij-u-2014mu-zu-pro-vishu-osvitu-zaprovadivbagato-potribnih-novacij-ale-sogodnivin-uzhe-zastariv-ta-potrebuyezmin

4. Стадний $\epsilon$. Українські студенти закордоном: факти та стереотипи [Електронний ресурс] / С. Стадний // Аналітичний центр CEDOS. 2017. Режим доступу : https:// cedos.org.ua/uk/articles/ukrainskistudenty-za-kordonom-fakty-tastereotypy

5. Федорченко Ю. Чи треба радикально міняти закон "Про вищу освіту”? [Електронний ресурс] / Ю. Федорченко // Освіта.ua. 2018. Режим доступу : https://osvita.ua/vnz/ reform/59677/

6. Стандарти і рекомендації щодо забезпечення якості в Європейському просторі вищої освіти (ESG) / пер. 3 англ. К. : ТОВ “ЦС”, 2015. 32 с.

7. Про вищу освіту : Закон України [Електронний ресурс] / Верховна Рада України ; від 01.07.2014 р. № 1556-VII. Режим доступу : http:/ / zakon4.rada.gov.ua/laws/show/155618

8. Про аудиторську діяльність : Закон України [Електронний ресурс] / Верховна Рада України ; від 22.04.1993 р. № 3125-XII. Режим доступу : http://zakon4.rada.gov.ua/ laws/show/3125-12 